\title{
Przedsiębiorczość w kształceniu studentów, dorosłych i seniorów
}

DOI: 10.47050/65591760.204-218

Grażyna Nowaczyk, Anna Sobczak

Celem artykułu jest omówienie przedsiębiorczości jako domeny badawczej, uporządkowanie terminologiczne związane z tą domeną, a także ukazanie głównych wyników badań prowadzonych w tym zakresie. Przedstawiono też wyniki badań dotyczących postaw przedsiębiorczych studentów. W obliczu starzenia się społeczeństw zwrócono uwagę na przedsiębiorczość seniorów, która staje się jednym z ważniejszych obszarów badań w krajach rozwiniętych.

\section{Słowa kluczowe:}

przedsiębiorczość

kształcenie

szkoła wyższa

przedsiębiorczość seniorów

przedsiębiorczość studentów 


\section{Entrepreneurship in the education of university students, adults and seniors}

DOI: $10.47050 / 65591760.204-218$

Grażyna Nowaczyk, Anna Sobczak

This paper aims to discuss the entrepreneurship as the research domain, as well as to organize the terminology associated with that domain, and to present the main findings of research conducted in this area. The article elaborates on the outcomes of a survey concerning student entrepreneurial attitudes and held on a sample of students of economic studies. Senior entrepreneurship is becoming one of the most important areas of research in developed countries, especially in the face of population aging in these countries. Prior studies have shown that older people in their third age are less inclined to take up economic activities and have lower entrepreneurial intentions than younger people in their prime age.

Keywords:

entrepreneurship

education, university

seniors' entrepreneurship

student entrepreneurship 


\section{Wstęp}

Przedsiębiorczość, uznawana za jedną z kluczowych kompetencji, nie jest jednoznacznie definiowana. Stąd jej nauczanie może obejmować swoim zakresem kształtowanie różnorodnych umiejętności. Często pojęcie przedsiębiorczości odnosi się do cech osobowości człowieka, procesu zakładania działalności gospodarczej oraz umiejętności wykorzystywania szans w otoczeniu i podejmowania działań innowacyjnych (Borowiec-Gabryś, Kilar, Rachwał 2018). Kształcenie przedsiębiorczości na poziomie wyższym dotyczyć może wszystkich trzech aspektów. Istnieje jednak potrzeba kształtowania postaw przedsiębiorczych, a w szczególności umiejętności zakładania działalności gospodarczej i jej rozwijania. Jak wynika ze Światowego Raportu Amway o Przedsiębiorczości AGER 2018, przygotowanego przez Instytut GfK pod patronatem Uniwersytetu Technicznego w Monachium1, skłonność Polaków do zakładania przedsiębiorstw zmniejsza się w ostatnich latach. W najnowszym badaniu chęć założenia własnej działalności deklarowało 27 proc. badanych Polaków, podczas gdy w 2016 r. było ich 32 proc. Z danych GUS wynika, że spośród utworzonych w 2017 r. podmiotów niefinansowych prowadzących działalność gospodarczą w 2018 r. działalność tę kontynuowały tylko dwa przedsiębiorstwa na trzy². W UE wskaźnik ducha przedsiębiorczości był wyższy niż w Polsce i wynosił 42 proc., a we wszystkich badanych państwach -47 proc. $^{3}$.

Możliwości prowadzenia analizy w tym zakresie są jednak ograniczone z uwagi na duże zróżnicowanie charakteru realizowanych kierunków studiów, kształtowanych kompetencji, wykorzystywanych metod kształcenia, a także dodatkowych aktywności sprzyjających rozwojowi przedsiębiorczości. Uczenie przedsiębiorczości na studiach wyższych powinno być dostosowane do poziomu, profilu i kierunku kształcenia. $\mathrm{Na}$ kierunkach ekonomicznych nauczanie przedsiębiorczości koncentruje się na budowaniu kompetencji związanych z zakładaniem

1. Badaniami objęto reprezentatywną próbę 50 tys. osób z 44 państw świata, w tym ponad 1 tys. Polaków.

2. Przedsiębiorstwa niefinansowe powstałe w 2017 r., stat.gov.pl/obszary-tematyczne/ podmioty-gospodarcze-wyniki-finansowe/przedsiebiorstwa-niefinansowe/przedsiebiorstwaniefinansowe-powstale-w-2017-roku,25,1.html (dostęp: 3.12.2018).

3. Światowy Raport Amway o Przedsiębiorczości AGER 2018, networkmagazyn.pl/swiatowyraport-amway-o-przedsiebiorczosci-ager-2018 (dostęp: 3.12.2018). 
działalności gospodarczej, ponieważ ze swej natury kierunki te kształtują różnego typu umiejętności biznesowe, natomiast na kierunkach technicznych kompetencje przedsiębiorcze mogą w większym stopniu obejmować umiejętności kreowania i wykorzystania pomysłów technologicznych, a na artystycznych - wykorzystania kreatywności do prowadzenia działalności na własny rachunek4.

\section{Programy studiów}

Znaczenie kształtowania kompetencji z zakresu przedsiębiorczości na studiach można rozpatrywać w kontekście analizy programów studiów. W 2016 r. przeprowadzono analizę programów studiów w czterech krajach z Grupy Wyszehradzkiej: w Czechach, Polsce, na Słowacji i Węgrzech. Analizie poddano łącznie 188 programów studiów (Egerova 2016). Badano programy studiów zarówno na kierunkach ekonomicznych (głównie ekonomia i zarządzanie), jak i na innych (technicznych, artystycznych, humanistycznych), na pierwszym oraz drugim stopniu. Badano po 50 proc. kierunków ekonomicznych i nieekonomicznych w każdym kraju. Wyniki analizy pokazują zakres nastawienia uczelni na kształtowanie postaw przedsiębiorczych, w szczególności w rozumieniu przygotowania do podejmowania i prowadzenia własnej działalności gospodarczej. $Z$ danych zawartych w tabeli 1 wynika, że około 40 proc. kierunków ma w programach studiów przedmiot (co najmniej jeden), który bezpośrednio dotyczy przedsiębiorczości. Są to przedmioty przygotowujące do otwarcia własnej działalności gospodarczej i na dodatek takie, które w nazwie mają słowo „przedsiębiorczość". W Polsce udział programów z co najmniej jednym przedmiotem bezpośrednio związanym z przedsiębiorczością jest najniższy i wynosi 31 proc. Poza tym na badanych kierunkach studiów realizowane są też przedmioty, które można powiązać z przedsiębiorczością, ponieważ dotyczą zagadnień związanych z funkcjonowaniem firmy. Są to np.: zarządzanie, marketing, rachunkowość, finanse, biznesplan, negocjacje - występują one kilkakrotnie częściej. Łącznie przedmioty bezpośrednio i pośrednio związane z przedsiębiorczością znajdowały się w programach studiów 93 proc. badanych kierunków.

4. Przedsiębiorczość w szkolnictwie wyższym, szczególnie na studiach nieekonomicznych, streszczenie Sprawozdania końcowego grupy ekspertów, Komisja Europejska, 2008, ec.europa.eu/docsroom/documents/8969/attachments/1/translations/pl/.../native, 3.12.2018. 
Tabela 1. Kierunki studiów z co najmniej jednym przedmiotem bezpośrednio związanym z przedsiębiorczością i bez przedmiotów związanych bezpośrednio i pośrednio z przedsiębiorczością

\begin{tabular}{l|c|c|c}
\multicolumn{1}{c|}{ KRAJ } & $\begin{array}{c}\text { LICZBA } \\
\text { ANALIZOWANYCH } \\
\text { KIERUNKóW } \\
\text { STUDIÓW }\end{array}$ & $\begin{array}{c}\text { PROCENT KIERUNKÓW } \\
\text { Z PRZEDMIOTEM/-AMI } \\
\text { BEZPOŚREDNIO ZWIAZZANYM/-MI } \\
\text { Z PRZEDSIĘBIORCZOŚCIĄ }\end{array}$ & $\begin{array}{c}\text { PROCENT KIERUNKÓW } \\
\text { BEZ PRZEDMIOTÓW } \\
\text { ZWIAZZANYCH } \\
\text { Z PRZEDSIĘBIORCZOŚCIA }\end{array}$ \\
\hline Czechy & 59 & 39 & 9 \\
\hline Węgry & 36 & 44 & 6 \\
\hline Polska & 42 & 31 & 7 \\
\hline Słowacja & 51 & 43 & 6 \\
\hline Ogółem & 188 & 39 & 7
\end{tabular}

Źródło: Na podstawie Entrepreneurship education. Opportunities and Challenges for Universities in Visegrad Countries, ed. by D. Egerova, NAVA, Pilzno 2016, tab. 4.3 i 4.5, s. 58-59.

W Polsce na badanych kierunkach studiów było łącznie 13 przedmiotów bezpośrednio związanych z kierunkiem studiów 162 pozostałe, które są przydatne w nauczaniu sposobów funkcjonowania przedsiębiorstw. Przedmioty bezpośrednio związane z przedsiębiorczością, mające w nazwie słowo "przedsiębiorczość", obejmowały swoim zakresem m.in. wiedzę z zakresu regulacji prawnych związanych z prowadzeniem działalności gospodarczej, źródeł wspierania przedsiębiorczości (inkubatory, instytucje oferujące dotacje i pożyczki), kształtowania umiejętności rejestrowania działalności gospodarczej, tworzenia biznesplanu przedsięwzięcia z uwzględnieniem ryzyka prowadzenia działalności gospodarczej czy analizy i oceny pomysłów biznesowych (Nowiński, Nowaczyk, Sobczak, Tomczyk, Fabiś 2016).

Z kolei analiza programów studiów pierwszego i drugiego stopnia dotycząca 15 kierunków ekonomicznych realizowanych na pięciu uczelniach w Polsce w zakresie ekonomii, finansów i rachunkowości oraz zarządzania wykazała, że na tych kierunkach przedmioty bezpośrednio i pośrednio związane z przedsiębiorczością stanowiły prawie jedną piątą ogólnej liczby przedmiotów realizowanych na kierunku i umożliwiały zdobycie 16 proc. punktów ECTS. Dodać jednak należy, że tylko na zarządzaniu realizowane były przedmioty bezpośrednio związane z przedsiębiorczością, na których omawiano takie zagadnienia jak np. zalety i wady prowadzenia własnego biznesu, osobowość przed- 
siębiorcy - cechy i predyspozycje przedsiębiorcy, tworzenie pomysłów na własną działalność, zakładanie działalności gospodarczej, formy organizacyjno-prawne przedsiębiorstw (Nowaczyk, Sobczak 2016).

Analizując z kolei materiały dostępne na stronie Szkoły Głównej Handlowej5, można zauważyć, że student rozpoczynający naukę w roku akademickim 2018/2019, niezależnie od kierunku na studiach pierwszego i drugiego stopnia, będzie znał formy rozwoju indywidualnej przedsiębiorczości, potrafił wykorzystywać posiadaną wiedzę w działalności zawodowej, w tym w prowadzeniu firmy na własny rachunek, i będzie gotów do myślenia i działania w sposób przedsiębiorczy. Kompetencje te są kształtowane w trakcie realizacji różnych przedmiotów. Na prowadzonych w SGH w języku polskim sześciu kierunkach studiów pierwszego stopnia tylko na zarządzaniu zaplanowano przedmiot mający w nazwie "przedsiębiorczość", co w dotychczasowym ujęciu oznacza, że jest bezpośrednio związany z przedsiębiorczością, natomiast na 13 kierunkach studiów drugiego stopnia taki przedmiot wystąpił na czterech kierunkach. Na wszystkich kierunkach studiów na tej uczelni realizowane są jednak (niekiedy nawet w dużej liczbie) także przedmioty związane z przedsiębiorczością, kształtujące różne umiejętności z zakresu funkcjonowania przedsiębiorstwa i jego rozwoju. Jest ich najwięcej na zarządzaniu.

Poza przedmiotami kształcącymi kompetencje z zakresu przedsiębiorczości pojawiają się na polskich uczelniach kierunki i specjalności z tego zakresu, na których bardziej kompleksowo podchodzi się do kształtowania omawianych w tym artykule kompetencji. Kierunek przedsiębiorczość jest prowadzony np. na Wydziale Prawa i Administracji Uniwersytetu Śląskiego w Katowicach. Z kolei przykładem specjalności z tego zakresu jest przedsiębiorczość w małej i średniej firmie, wykładana na studiach drugiego stopnia kierunku zarządzanie na Wydziale Zarządzania Uniwersytetu Ekonomicznego w Poznaniu (Nowiński, Nowaczyk, Sobczak, Tomczyk, Fabiś 2016).

\section{Nauczanie przedsiębiorczości w opinii studentów studiów stacjonarnych i niestacjonarnych}

Na podstawie przeprowadzonych badań fokusowych (lata 2016 i 2018) wśród studentów kierunków ekonomicznych (zarządzania, ekonomii

5. Strona internetowa SGH: dziekanat.sgh.waw.pl/informatory/informator_2018_opis_sl_sm.pdf (dostęp: 27.11.2018). 
i logistyki) zdiagnozowano wpływ nauczania przedsiębiorczości studentów na kształcenie postaw przedsiębiorczych i wspieranie inicjatyw przedsiębiorczych podejmowanych na poziomie regionalnym, krajowym czy globalnym przez studentów. Zebrane opinie i sugestie pozwoliły na wskazanie zmian, które powinny podejmować uczelnie, by lepiej przygotować młodych ludzi do przedsiębiorczości.

Studenci kierunków ekonomicznych podczas badań fokusowych podkreślali, że niezbędna jest nauka przedsiębiorczości, szczególnie na studiach ekonomicznych, ponieważ jest to grupa studentów, która w przyszłości ma zajmować się szeroko rozumianym biznesem. Wszystkie badane grupy wskazywały, że nauka przedsiębiorczości, pomimo że jest realizowana od szkoły gimnazjalnej, skupia się na wiedzy teoretycznej, a nie na wykształcaniu stosownej postawy wśród młodych ludzi. Zdaniem studentów przedsiębiorczość jako przedmiot albo nie funkcjonuje w planie studiów, albo jego formuła sprowadza się do kilku zajęć, które niewiele wnoszą do kształcenia. Studenci, którzy mieli taki przedmiot, nie wskazywali, aby zasadniczo wpłynął on na ich postawę przedsiębiorczą. Na studiach od roku 2016 (kiedy przeprowadzono pierwsze badanie) do 2018 r. (kiedy powtórzono badanie) nie zmieniła się formuła kształcenia przedmiotu i w dalszym ciągu nie uczy się studentów przedsiębiorczości praktycznej.

Nieliczna grupa studentów, która już podczas studiów prowadziła swoją działalność gospodarczą, wskazywała, że zajęcia z przedsiębiorczości powinny być prowadzone, ponieważ jest to najlepszy sposób na zachęcenie nowych osób do podejmowania własnych inicjatyw i zmobilizowania do większej aktywności gospodarczej. Zdaniem tej grupy studentów edukacja przedsiębiorczości powinna być prowadzona na każdym szczeblu edukacji. Z kolei na studiach ekonomicznych powinna być obowiązkowa i objęta szczególną troską zarówno uczelni, jak i administracji państwowej. Badani podkreślali, że przedsiębiorczość powinna być kursem realizowanym na każdym kierunku studiów, ponieważ gospodarka rynkowa wymaga, by przedstawiciele każdego kierunku potrafili myśleć o swojej dziedzinie jako biznesie. To nowe spojrzenie na przedsiębiorczość pokazuje, że młodzi ludzie z doświadczeniami biznesowymi dostrzegają istotę przedsiębiorczości i kreowania jej u przedstawicieli wszystkich kierunków studiów.

Studenci podkreślali podczas badań, że dużą wagę w całym kształceniu przywiązuje się do ukazywania tematu uruchomienia własnej 
firmy. Wiedza, którą otrzymują podczas zajęć, mimo że jest podparta często przykładami, okazuje się niewystarczająca i w efekcie studenci nie wiedzą, jakie kroki podjąć, aby otworzyć działalność. Wskazywali też, że po skończeniu kursu z przedsiębiorczości raczej obawiali się zakładać swoją firmę, ponieważ na zajęciach wskazywano także na trudności i problemy, na które mogą natrafić na swojej drodze. Często właśnie te czynniki i strach przed nieznanym hamowały ich przed otwieraniem działalności. Kolejnym zniechęcającym czynnikiem był brak jakiegokolwiek wsparcia w tym zakresie ze strony państwa. Badani wskazywali często, że nie wiedzą, do jakich urzędów muszą pójść, jak wypełniać dokumenty, gdzie i kogo pytać o porady oraz jaką formę prawną działalności wybrać. Problemem jest także planowanie działań, analizowanie oferty konkurencji, działania marketingowe produktu czy usługi lub całość spraw związanych z częścią kadrowo-finansową. Studenci obawiali się, że w przypadku pytań lub problemów nie będą wiedzieli, gdzie szukać pomocy. Przykłady, które podawali ich koledzy i koleżanki prowadzący już działalność, potwierdzały te obawy.

Osoby, które w trakcie trwania badania prowadziły firmy, twierdziły, że uczęszczając na studiach na zajęcia z przedsiębiorczości i korzystając tylko z nich, nie podjęłby decyzji o otwarciu własnej działalności. Ich zdaniem zajęcia dają tylko informacje, ale nie pozwalają przećwiczyć całego procesu. Zajęcia były ich zdaniem zbyt teoretyczne i nie pokazywały, jak krok po kroku, mając pomysł, założyć działalność. Część badanych wskazała także, że liczba zajęć była niewystarczająca, by można było takie ćwiczenia przeprowadzić. Ponadto młodzi ludzie stwierdzili, że wiedza potrzebna do prowadzenia własnej działalności jest rozproszona na kilku, a nawet kilkunastu przedmiotach, i nie ma jednego przedmiotu spinającego te wiadomości (Nowiński, Nowaczyk, Sobczak, Tomczyk, Fabiś 2016).

Studenci prowadzący swoje firmy wskazywali, że przy ich zakładaniu korzystali z pomocy innych - firm zewnętrznych lub osób, które przeszły już tę ścieżkę i mogły być dla nich drogowskazem. Większość wskazywała na pomoc rodziny w tym obszarze. Stwierdzali, że edukację dla przedsiębiorczości powinny prowadzić uczelnie, a wykładowców wskazywali jako tych, którzy powinni ukierunkowywać, motywować studentów i umacniać ich w dążeniach do zakładania własnych biznesów. W badaniach pojawiły się sugestie, że wykładowcy bardzo często przekazują tylko wiedzę, ale nie motywują studenta do działań w realnym 
biznesie. Ponadto studenci często zwracali uwagę na jedynie teoretyczne przygotowanie wykładowców. Zdaniem badanych dydaktyk niemający praktyki w prowadzeniu biznesu nie potrafi dostatecznie zainteresować tym tematem studentów, a także motywować ich do posiadania własnego biznesu. Brak doświadczeń z biznesu u wykładowców był odbierany przez studentów jako słabe przygotowanie kadry do prowadzenia zajęć. Młodzi ludzie zwracali też uwagę na to, że na uczelniach brakuje praktyków, którzy przez dłuższy czas spotykaliby się z młodymi ludźmi i zachęcali ich do otwierania działalności gospodarczej. Studenci stwierdzili, że jeden kurs nie spowoduje znaczącego wzrostu zainteresowania otwieraniem firm i potrzebne są działania długofalowe, trwające przez cały okres studiów.

W opinii badanych bardzo ważna jest wiedza na temat uruchomienia własnej firmy, ale także umiejętności jej prowadzenia, np. wypełnianie odpowiednich dokumentów czy sprawy podatkowe lub prawne. Studenci zdają sobie sprawę też z tego, że aby prowadzić firmę i ją rozwijać, potrzebne są wiedza i umiejętności z zakresu zarządzania. Mimo że badanie było przeprowadzone na kierunkach ekonomicznych, na uwagę zasługuje to, że studenci logistyki i ekonomii wskazywali na braki zarówno w wiedzy i umiejętnościach z dziedziny zarządzania (ludźmi, kosztami i dochodami, czasem), jak i rachunkowości, finansów czy prawa cywilnego i handlowego. Grupa studentów z tych kierunków wprost mówiła, że absolwenci kierunku zarządzanie są lepiej przygotowani do prowadzenia swojego biznesu. Ten wniosek jest ważny w kontekście innych kierunków, na których - jak pokazują badania - uczelnie wręcz wcale albo rzadko w rozkładach zajęć planują przedmioty z zakresu zarządzania. Badani podkreślali też, że sukces na rynku nie zależy wyłącznie od wiedzy i samego pomysłu na biznes, ale od kreatywności, umiejętności planowania, zarządzania czasem, umiejętności pracy w grupie, radzenia sobie ze stresem czy podejmowania ryzyka. Studenci wszystkich kierunków wskazywali, że w czasie studiów bardzo rzadko ćwiczą na zajęciach zarówno te umiejętności, jak i kreatywne rozwiązywanie problemów (Nowiński, Nowaczyk, Sobczak, Tomczyk, Fabiś 2016).

Dla uczestników badania bardzo ważną rolę odgrywają praktyki studenckie, wizyty w firmach, spotkania z ludźmi sukcesu lub osobami, które prowadzą firmy i chcą się dzielić swoim doświadczeniem. Taki praktyczny aspekt kształcenia jest postrzegany jako okazja do słucha- 
nia, podpatrywania i uczenia się od osób, które mają wiedzę praktyczną i uczą, jak postępować w określonych sytuacjach. Studenci wysoko oceniają organizowane spotkania z ciekawymi osobami, pokazujące, jaką drogę biznesową przeszły te osoby oraz z jakimi problemami, wyzwaniami czy wręcz oporem i trudnościami musiały się zmierzyć. Jak podkreślali, wartościowsze jest spotkanie z człowiekiem, który opowiada o prowadzeniu biznesu, pokazując jego ciemne strony i sposoby wychodzenia z tych kryzysów, niż opowiadanie tylko o pozytywach prowadzenia biznesu. Studenci podczas praktyk studenckich chcieliby uczyć się prowadzenia biznesu, ale zdają sobie sprawę z tego, że przedsiębiorcy nie mają czasu, aby poświęcić im dostateczną część uwagi.

Wyniki badania pokazały, że w większości studenci po zakończeniu nauki ani nie są gotowi, ani nie planują otworzyć swojej firmy. Wśród argumentów przeciw zakładaniu własnego przedsiębiorstwa najczęściej wskazywali brak środków finansowych - studenci, którzy chcą wziąć kredyt na otwarcie działalności, stanowili 1 proc. wszystkich badanych. Kolejnym czynnikiem jest strach przed nieznanym oraz tzw. wygodnictwo - „lepiej pracować u kogoś i nie mieć zmartwień, zrobić swoje i mieć wolne". Badani wskazywali także, że rodzina i przyjaciele (którzy najczęściej pracują na etacie) odradzają im otwieranie własnego biznesu, twierdząc, że jest to bardzo trudne i nie ma żadnych gwarancji na powodzenie. Studenci przyznawali, że są zbyt młodzi na prowadzenie własnej firmy i wciąż chcą mieć czas na relaks i życie towarzyskie. Takie postawy wskazują na nieracjonalne szukanie wytłumaczeń i niechęć do podejmowania nowej inicjatywy. Szukanie złych stron prowadzenia własnej działalności można zinterpretować jako szukanie wytłumaczenia wygodnictwa, na które skazują się młodzi ludzie. Studenci, myśląc o sobie na rynku pracy, widzą siebie raczej jako pracowników, a nie jako pracodawców. Taka sytuacja potwierdza ogólny nastrój niechęci do zakładania własnego biznesu. Młodych ludzi w prowadzeniu swojej firmy pociągają najczęściej pieniądze i możliwość elastycznego czasu pracy jako wartości. Jednak zdają sobie sprawę, że zarobienie wystarczającej i satysfakcjonującej sumy pieniędzy może być rozciągnięte w czasie.

Z kolei badane osoby, które już prowadziły działalność, nie podejmowały tematu pieniędzy, a czynnik „elastyczny czas pracy” oznaczał dla nich pracę przez 24 godziny na dobę. Ta grupa badanych ochoczo wypowiadała się o argumentach za otwarciem własnej firmy i prze- 
ciw niemu, chętnie nawiązywała do własnych problemów i dzieliła się doświadczeniami. Do prowadzenia własnej działalności najczęściej zachęcały ją: możliwość decydowania o sobie, budowania czegoś trwałego dla swojej rodziny, elastyczny czas pracy oraz korzyści finansowe.

Warto też zwrócić uwagę na optymistyczne stwierdzenie osób, które $w$ trakcie trwania badania pomagały swoim bliskim w prowadzeniu firmy - obecnie chcą zdobyć doświadczenie, pracując u kogoś innego, lub zaoszczędzić pieniądze na własny biznes, a w przyszłości założyć swoją działalność. Część studentów, których bliscy lub znajomi prowadzą działalność, liczy w przyszłości na ich pomoc przy otwieraniu własnej. Wszyscy podkreślali, że jeśli spotykają na co dzień osoby prowadzące działalność, które są zadowolone z siebie i zmotywowane, to taka postawa działa na nich również motywująco. Wniosek: spełnieni przedsiębiorcy zarażają innych swoim entuzjazmem i zachęcają do realizacji własnych planów oraz marzeń o działalności. Studenci wskazywali, że obserwują osoby prowadzące własny biznes oraz rozmawiają z nimi i z tych doświadczeń czerpią siłę oraz zapał do zakładania własnego biznesu.

Badani, którzy nie prowadzą samodzielnie działalności, zapytani, czy mają wystarczającą ilość informacji, by uruchomić firmę, odpowiedzieli, że nie. Wiedzy na temat otwarcia biznesu poszukują najczęściej w internecie. Tylko nieliczni wskazali, że przy zakładaniu działalności kontaktowaliby się ze swoimi wykładowcami z uczelni.

Opinie na temat pomysłów na poprawę kształcenia przedsiębiorczości na uczelniach i budzenia wśród studentów ducha przedsiębiorczości były podzielone. Jedni wskazywali na większą liczbę ćwiczeń wykonywanych samodzielnie i podejmowanie decyzji tak, aby późniejsze rezultaty omawiać na zajęciach. Były też osoby, którym odpowiadałyby zajęcia z prowadzenia firmy najlepiej w postaci gry komputerowej. Kolejne wskazywały na odbywanie wizyt studyjnych w firmach i instytucjach oraz spotkania z przedsiębiorcami, którzy mogliby opowiadać o prowadzeniu własnego biznesu wraz z możliwością zadawania pytań (Nowaczyk, Sobczak 2016).

\section{Przedsiębiorczość wśród seniorów}

Przedłużenie długości życia i poprawa ogólnej zdrowotności społeczeństw krajów wysoko rozwiniętych spowodowały, że okres aktywności zawodowej ludności znacznie się wydłużył. Przedsiębiorczość 
wśród seniorów dotyczy zarówno osób z grupy 50+, jak i tych, które są już w wieku emerytalnym. Z analizy badań własnych przeprowadzonych w 2018 r. na uniwersytetach trzeciego wieku, raportów badań przeprowadzonych w Europie i dostępnej literatury wynika, że skłonność do podejmowania własnej działalności gospodarczej maleje wraz z wiekiem (Wach 2015). Przedsiębiorczość grupy 50+ w Polsce wynika z wywierania wpływu przez pracodawców na tę grupę, aby współpracowała z przedsiębiorstwami jako grupa samozatrudnionych. Grupa ta zakłada własną działalność, ponieważ tylko w taki sposób może w dalszym ciągu pracować na danym stanowisku i wykonywać pracę. Przedsiębiorcy, eliminując koszty osobowe, zachęcają swoich pracowników do prowadzenia samodzielnie działalności, mimo że spora część z nich nie chce takiego rozwiązania. Mówimy wtedy o "wymuszonej przedsiębiorczości", kiedy to impuls do otwarcia działalności nie pochodzi od osoby, ale jest jej narzucony przez otoczenie. Często dojrzali przedsiębiorcy w wieku emerytalnym nie rezygnują z prowadzenia firmy, nawet jeśli osiągnęli wysoką pozycję materialną i ich bieżące oraz przyszłe potrzeby materialne są już zabezpieczone.

Członkowie uniwersytetu trzeciego wieku, wśród których były prowadzone badania w 2018 r., wskazali, że brakuje im postaw przedsiębiorczych, a co za tym idzie - tylko około 2 proc. respondentów myślało o zakładaniu własnego przedsiębiorstwa. Tak niski wskaźnik potwierdza miejsce Polski wśród grupy krajów o najniższym wskaźniku aktywności przedsiębiorczej seniorów, skonstruowanym na podstawie badań przeprowadzonych w 28 krajach Unii Europejskiej (por. Pilkova, Holienka, Rehak 2014). Seniorzy nie chcą podejmować nowych form działalności i aktywności, powołując się na to, że już są na emeryturze i chcą odpoczywać, a nie pracować. Stwierdzają, że to młodzi powinni zakładać nowe firmy, a nie oni. Taka postawa potwierdza wyniki badań światowych o tym, że emeryci w Polsce nie są zainteresowani podejmowaniem aktywności zawodowej poprzez otwieranie działalności. Nieliczna grupa, która decyduje się na to najczęściej, podjęła decyzję o przejściu na emeryturę przed 60. rokiem życia. Zakładają oni działalność, ponieważ są zdrowi, chcą robić nowe rzeczy, chcą pozostawać aktywni zawodowo i realizować się w ten sposób. Bardzo rzadko impulsem do zakładania firmy są pobudki finansowe. Seniorzy chcą się realizować, spełniać swoje marzenia i czuć się potrzebni. Czasami podejmują decyzję o zakładaniu własnej firmy, ponieważ nie mogą 
znaleźć zatrudnienia u pracodawców i jest to jedyne rozwiązanie, aby dalej pozostawać na rynku pracy.

W wyniku starzenia się społeczeństw rynek pracy się zmienia i obecni pracownicy z grupy 50+ będą podejmować częściej decyzję o założeniu działalności. Właśnie taka forma będzie gwarantowała im zatrudnienie $u$ dotychczasowego pracodawcy lub pozwalała pozostawać na rynku pracy. Ponadto pojawia się coraz więcej wolnych zawodów i ludzie wykonujący daną pracę nie myślą o odejściu na emeryturę. Wydaje się, że tak w przyszłości będzie wyglądał rynek pracy seniorów - będą oni aktywni zawodowo, ale będą wybierać między ofertami, uwzględniając możliwości fizyczne, stopień zaangażowania oraz potrzeby finansowe.

\section{Podsumowanie}

Bardzo mały odsetek młodych ludzi podejmuje się otwarcia swojego biznesu. Młodym wygodniej jest pracować u innych, natomiast seniorzy chcą pracować dla siebie, bo już napracowali się dla kogoś. Seniorzy rzadziej podejmują decyzję o otwieraniu działalności ze względów finansowych, natomiast dla młodych ludzi jest to jeden z najważniejszych argumentów przy podejmowaniu decyzji. Starsze osoby wykazują mniejszą niż młodzi skłonność do przebranżowienia się i wprowadzania innowacji podczas otwierania swojej działalności. W porównaniu z ludźmi młodymi rozpoczynającymi karierę biznesową atutami seniorów są: wiedza, doświadczenie oraz kontakty. Prowadzenie firmy będzie wymagało dużego wysiłku, w tym umiejętności radzenia sobie ze stresem i podejmowania ryzyka, czego mogą obawiać się seniorzy. Studenci i seniorzy to dwie grupy nastawione na rozwój, jednak ich spojrzenie na przedsiębiorczość i podejmowanie decyzji o otwieraniu działalności jest bardzo odmienne. Właśnie ta odmienność powoduje, że każda z tych grup ma szansę na rynku pracy. 


\section{Bibliografia}

$\rightarrow$ Borowiec-Gabryś, M., Kilar, W., Rachwał, T. (2018), Przedsiębiorczość jako kompetencja przyszłości [w:] Kompetencje przyszłości, S.M. Kwiatkowski (red.), Warszawa: Wydawnictwo FRSE, s. 74.

$\rightarrow$ Entrepreneurship education. Opportunities and Challenges for Universities in Visegrad Countries, ed. by D. Egerova (2016), Pilzno: NAVA, s. 56-57.

$\rightarrow$ Nowaczyk, G., Sobczak, A., Role of entrepreneurship education in higher education institutions in the proces of business development in Poland [w:] Entrepreneurship: Antecedents and Effects, ed. by M. Kosała, M. Urbaniec, A. Żur, „Przedsiębiorczość Międzynarodowa", nr 2/2016, s. 43-52.

$\rightarrow$ Nowiński, W., Nowaczyk, G., Sobczak, A., Tomczyk, Ł., Fabiś, A. (2016), Innowacyjna edukacja przedsiębiorczości, Raport krajowy, Poznań-Oświęcim-Kraków: Wyższa Szkoła Bankowa w Poznaniu, Państwowa Wyższa Szkoła Zawodowa w Oświęcimiu, Uniwersytet Pedagogiczny w Krakowie, s. 21-27, 31-38.

$\rightarrow$ Pilkova, A., Holienka, M., Rehak, J. (2014), Senior Entrepreneurship in the Perspective of European Entrepreneurial Environment, „Procedia Economics and Finance", nr 12, s. 523-532, doi: 10.1016/S2212-5671(14)00375 - X.

$\rightarrow$ Wach, K. (2015), Przedsiębiorczość seniorów jako komponent przedsiębiorczości inkluzywnej: wstępna synteza, „Horyzonty Wychowania”, Vol. 14, No 32. 


\section{Netografia}

$\rightarrow$ Przedsiębiorstwa niefinansowe powstałe w 2017 rok, tat.gov.pl/obszary-tematyczne/podmioty-gospodarcze-wyniki-finansowe/przedsiebiorstwa-niefinansowe/przedsiebiorstwa-niefinansowe-powstale-w-2017-roku,25,1.html (dostęp: 3.12.2018).

$\rightarrow$ Przedsiębiorczość w szkolnictwie wyższym, szczególnie na studiach nieekonomicznych, Streszczenie Sprawozdania końcowego grupy ekspertów, Komisja Europejska, 2008, ec.europa.eu/docsroom/documents/8969/attachments/1/ translations/pl/.../native (dostęp: 3.12.2018).

$\rightarrow$ Studia pierwszego i drugiego stopnia w SGH. Programy i plany studiów, dziekanat.sgh.waw.pl/informatory/informator_2018_opis_sl_sm.pdf (dostęp: 27.11.2018).

$\rightarrow$ Światowy Raport Amway o przedsiębiorczości AGER 2018, networkmagazyn.pl/ swiatowy-raport-amway-o-przedsiebiorczosci-ager-2018 (dostęp: 3.12.2018). 